\title{
Penilaian Sistem Suntikan Gas Biohidrogen menerusi Tetapan Arduino menggunakan Kultur Mikroalga Tempatan melalui Kaedah Fermentasi Fotosintesis dan Gelap
}

(Assessment of Biohydrogen Injection System through Arduino Setting in Photosynthetic and Dark Fermentation by Local Microalgae Culture)

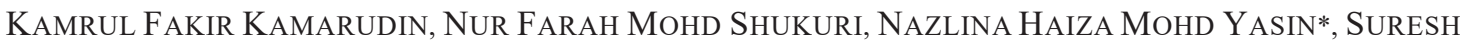 \\ THANAKODI, AZIZI MISKON \& MOHD SOBRI TAKRIFF
}

\begin{abstract}
ABSTRAK
Biohidrogen (gas hidrogen yang terhasil melalui kaedah biologi) ialah salah satu sumber tenaga mampan yang boleh diaplikasi untuk penjanaan elektrik. Hasil tindak balas pembakaran gas hidrogen menghasilkan air tanpa pelepasan gas rumah hijau. Mikroalga merupakan salah satu mikroorganisma yang boleh menghasilkan biohidrogen secara fermentasi fotosintesis dan gelap. Dalam kajian ini, mikroalga tempatan, Chlamydomonas sp. UKM6 telah digunakan untuk menghasilkan biohidrogen menggunakan kedua-dua kaedah fermentasi dalam keadaan anaerobik. Fermentasi fotosintesis dijalankan menggunakan kultur UKM6 yang hidup di bawah sinaran cahaya manakala fermentasi gelap dijalankan dengan menggunakan biojisim UKM6 yang diinokulasi dengan enapcemar daripada efluen kilang kelapa sawit (POME). Gas hidrogen yang terhasil disuntik secara automatik ke dalam sistem sel bahan api menggunakan Arduino Uno yang telah dibangunkan. Dengan menggunakan data yang dipaparkan daripada program tetapan Arduino, biojisim UKM6 dalam fermentasi gelap menghasilkan gas hidrogen dan nilai voltan purata tertinggi masing-masing pada kepekatan 30.89 ppm dan $0.92 \mathrm{mV}$. Berdasarkan keputusan yang diperoleh, dapat disimpulkan bahawa mikroalga berpotensi menjana tenaga melalui penghasilan biohidrogen yang dapat terus dianalisa menggunakan teknologi sel bahan api. Sistem ini jelas dapat dapat diperbaiki lagi pada masa akan datang untuk mengukur penjanaan tenaga secara terus dengan berkesan.
\end{abstract}

Kata kunci: Arduino uno; biohidrogen; Chlamydomonas sp.; sel bahan api

\section{ABSTRACT}

Biohydrogen (a hydrogen gas produced by biological methods) is one of the most sustainable sources of energy for electricity generation. Hydrogen gas combustion produces only water without the release of greenhouse gases emission. Microalgae are the microorganisms that can produce biohydrogen through photosynthesis and dark fermentation. In this study, the local microalgae isolate, Chlamydomonas sp.UKM6 has been used to generate biohydrogen using both fermentation methods under anaerobic conditions. Photosynthesis fermentation was carried out using the live culture of UKM6 under continuous illumination while dark fermentation was carried out using the biomass of UKM6 with the palm oil mill effluent (POME) sludge as an inoculum. The resulting hydrogen gas is automatically injected into the fuel cell system using the newly developed Arduino Uno. Using data presented from the Arduino settings program, the biomass of UKM6 in dark fermentation produces the highest hydrogen gas and voltage at $30.89 \mathrm{ppm}$ and $0.92 \mathrm{mV}$, respectively. Based on the results, it can be concluded that microalgae have the potential to generate energy through the production of biohydrogen which can be further analyzed using fuel cell technology. This system can be further improved in the future to measure energy generated directly and effectively.

Keywords: Arduino uno; biohydrogen; Chlamydomonas sp.; fuel cell

\section{PENGENALAN}

Sumber tenaga utama yang digunakan pada masa kini merupakan bahan bakar berunsur karbon seperti arang batu, petroleum dan cecair gas asli. Pembakaran sumber yang berasaskan karbon ini menghasilkan gas rumah hijau (GHG) seperti gas metana, karbon monoksida dan karbon dioksida. 
Sehubungan itu, penyelidik giat mencari sumber alternatif untuk menggantikan sumber tenaga kepada sumber yang lebih mesra alam. Justeru, gas hidrogen merupakan salah satu alternatif yang kini menjadi tumpuan penyelidik kerana ia mempunyai keupayaan menjana tenaga melalui kaedah pembakaran secara terus atau penjanaan elektrik menggunakan sel fuel (Jones \& Mayfield 2012). Hidrogen juga diakui sebagai sumber tenaga yang bersih dan lestari kerana hasil penggunaan gas ini tidak menjana GHG.

Namun, terdapat beberapa cabaran yang membantutkan perkembangan teknologi tenaga bersumberkan hidrogen. Antara faktor utama ialah proses penjanaan tenaga daripada sumber hidrogen yang masih belum berkembang. Pada masa kini, kebergantungan kepada sistem sedia ada berasaskan petroleum dan gas asli bagi menjana sumber tenaga adalah sangat tinggi. Sehingga kini, penghasilan gas hidrogen secara pukal dijalankan melalui proses pembentukan semula stim daripada gas asli. Selain daripada gas asli, sumber berasaskan petroleum seperti nafta dan sebahagian daripada arang batu teroksida juga digunakan sebagai bahan asas dalam proses penghasilan gas hidrogen. Oleh itu, terdapat pendapat yang menjurus bahawa sumber tenaga berasaskan hidrogen yang terhasil daripada sumber petroleum adalah tidak mesra alam. Sehubungan itu, penyelidik mencari sumber alternatif bagi penghasilan gas hidrogen melalui kaedah yang lebih lestari. Antara kaedah mampan adalah dengan menggunakan mikroorganisma yang berupaya menghasilkan gas hidrogen (Miskon et al. 2016).

Mikroalga merupakan salah satu mikroorganisma yang berupaya menjana gas hidrogen melalui kaedah fermentasi fotosintesis dan gelap (Anwar et al. 2019; Bolatkhan et al. 2019). Proses fotosintesis yang dijalankan oleh mikroalga menggunakan karbon daripada pelbagai sumber organik dan tidak organik yang menghasilkan biojisim dan gas oksigen. Namun, melalui beberapa kaedah, proses fotosintesis ini boleh dieksploitasi untuk penghasilan hidrogen. Kaedah yang sering diguna pakai bagi penghasilan gas hidrogen melalui mikroalga ialah dengan mengkultur mikroalga menggunakan media pertumbuhan yang tidak mempunyai unsur sulfur yang memangkin keadaan anaerobiosis di dalam kultur (Anandraj et al. 2019). Ketiadaan unsur sulfur semasa proses pengkulturan mikroalga mengubah laluan tindak balas yang terdapat pada sistem fotosintesis dan menghasilkan hidrogen sebagai hasil tindak balas berbanding oksigen.

Ramai penyelidik yang telah melaporkan bahawa biojisim mikroalga mempunyai potensi besar untuk diaplikasikan dalam pelbagai bidang. Salah satu aplikasi biojisim mikroalga adalah untuk digunakan sebagai substrat tambahan untuk penjanaan biohidrogen. Kajian oleh Templeton et al. (2012) telah menunjukkan bahawa $10-20 \%$ daripada komposisi biojisim mikroalga adalah karbohidrat yang boleh digunakan sebagai sumber karbon bagi bakteria asidogenik semasa proses fermentasi anaerobik. Selain itu, Becker (2007) juga telah menyimpulkan bahawa biojisim mikroalga dari spesies Chlamydomonas reinhardtii mempunyai komposisi karbohidrat, protein dan lipid masing-masing sebanyak 17, 48 dan 21\%. Terdapat hasil kajian terdahulu yang menggunakan biojisim mikroalga sebagai sumber karbon untuk menghasilkan gas hidrogen melalui proses fermentasi gelap (Kumar et al. 2019). Kaedah fermentasi anaerobik ini menghasilkan gas hidrogen melalui kaedah pencuraian bahan organik di dalam biojisim mikroalga yang dilakukan oleh bakteria hidrolitik, asidogenik dan asetogenik (Mohd Yasin et al. 2017). Disebabkan keunikan dan kebolehupayaan mikroalga dalam menghasilkan gas hidrogen, banyak kajian yang telah dilakukan bagi membuktikan potensi sebenar mikroalga.

Selain penghasilan gas hidrogen, proses kualitatif dan kuantitatif gas hidrogen yang terhasil adalah sangat penting bagi membuktikan ketelusan hasil kajian. Kajian terdahulu menggunakan kromatografi gas (GC) bagi mengenal pasti dan mengukur kepekatan gas hidrogen secara tepat. Selain menggunakan GC, terdapat juga kaedah yang menggunakan sensor dan sistem fotobiologikal untuk mengesan kepekatan gas hidrogen (Miskon et al. 2016). Terdapat dua cip mikropemproses yang sering digunakan iaitu Arduino Uno dan Rasberry Pi yang boleh disambungkan kepada pelbagai jenis sensor bagi memantau bacaan semasa uji kaji yang sedang dijalankan (Oltean 2019). Penggunaan cip mikropemproses ini menggunakan teknologi Internet of Things (IoT) yang boleh mengumpul maklumat secara segerak (Bisták 2019). Sistem Arduino Uno lebih mudah untuk digunakan kerana perisian pemproses yang lebih laju, program bahasa $(\mathrm{C}, \mathrm{C}++)$ yang mampu menukar maklumat analog kepada digital dengan lebih mudah dan harga yang berpatutan (Yang et al. 2019). Justeru, sistem ini menarik minat penyelidik dalam membantu mengumpul data secara masa nyata. Dalam kajian ini, peranti mudah alih yang murah menggunakan sistem Arduino telah dibina bagi mengukur kepekatan gas hidrogen yang terhasil. Oleh itu, pembangunan sistem suntikan gas hidrogen secara automatik dengan menggunakan gas hidrogen yang terhasil daripada fermentasi kultur mikroalga telah diguna pakai bagi menentukan kuantiti gas hidrogen yang terhasil secara terus. Justeru, kajian ini penting bagi memperkenalkan kaedah penentuan dan pemantauan kuantiti gas hidrogen 
secara terus.

\section{BAHAN DAN KAEDAH}

\section{PENGKULTURAN MIKROALGA}

Mikroalga Chlamydomonas sp. UKM6 (nombor pendaftaran NCBI: KP898730) telah digunakan dalam kajian ini. Chlamydomonas sp. UKM6 dikultur menggunakan media Bold Basal (BBM) yang mengandungi $\mathrm{NaNO}_{3}$, $\mathrm{MgSO}_{4} \cdot 6 \mathrm{H}_{2} \mathrm{O}, \mathrm{NaCl}, \mathrm{K}_{2} \mathrm{HPO}_{4}, \mathrm{KH}_{2} \mathrm{PO}_{4}, \mathrm{CaCl}_{2} .2 \mathrm{H}_{2} \mathrm{O}$, $\mathrm{ZnSO}_{4} \cdot 7 \mathrm{H}_{2} \mathrm{O}, \mathrm{MnCL}_{2} \cdot 4 \mathrm{H}_{2} \mathrm{O}, \mathrm{MoO}_{3}, \mathrm{CuSO}_{4} .5 \mathrm{H}_{2} \mathrm{O}$, $\mathrm{Co}\left(\mathrm{NO}_{3}\right)_{2} \cdot 6 \mathrm{H}_{2} \mathrm{O}, \mathrm{H}_{3} \mathrm{BO}_{3}$, EDTA, $\mathrm{FeSO}_{4} \cdot 2 \mathrm{H}_{2} \mathrm{O}$ dan $\mathrm{H}_{2} \mathrm{SO}_{4}$ (Hazman et al. 2018). Chlamydomonas sp. UKM6 telah dikultur dengan secara statik dan diadukkan. Kaedah pertama ialah pengkulturan secara statik, UKM6 hanya didedahkan kepada sumber cahaya tanpa pengadukan. Kaedah kedua ialah pengkulturan mikroalga dengan pengadukan menggunakan pengaduk mendatar pada kelajuan $100 \mathrm{rpm}$. Perbandingan antara pengkulturan mikroalga secara statik dan pengadukan dilihat pada perbezaan kepada kepekatan sel mikroalga menggunakan hemositometer. Sampel diukur sebanyak lima kali bagi memastikan kejituan hasil. Penggunaan hemositometer diukur dengan menghitung sel-sel mikroalga yang tercakup di ruang grid-sel hemositomer. Menggunakan ruang gridsel hemositomer yang berukuran $1 \mathrm{~mm}^{2}$, bilangan sel mikroalga hidup yang dihitung dapat dikuantifikasikan (sel/mL) dengan menggunakan formula berikut:

Bilangan sel $(\mathrm{sel} / \mathrm{mL})=$ Bilangan sel yang dihitung dalam ruang $1 \mathrm{~mm}^{2} \times 10^{4}$

\section{ASAI BIOHIDROGEN}

Chlamydomonas sp. UKM6 yang telah dikultur menggunakan kaedah statik dan pengadukan digunakan terus untuk pengkulturan di dalam kajian fermentasi fotosintesis dan gelap. Dalam kultur fermentasi fotosintesis, Chlamydomonas sp. UKM6 dikulturkan di dalam BBM steril yang telah diubah suai tanpa unsur sulfur. Sebanyak $120 \mathrm{~mL}$ kultur UKM6 dicampurkan bersama media BBM sehingga mencapai isipadu sebanyak $400 \mathrm{~mL}$ di dalam botol Duran bersaiz $500 \mathrm{~mL}$. Uji kaji kawalan telah dilakukan dengan menggantikan komposisi UKM6 dengan air suling yang steril. Kemudian, oksigen terlarut di dalam botol Duran disingkirkan dengan menyalurkan gas nitrogen selama 10 min. Pengkulturan mikroalga melalui fermentasi fotosintesis dijalankan secara anaerobik dalam keadaan statik dan diaduk menggunakan mesin pengaduk mendatar pada kelajuan $100 \mathrm{rpm}$. Rajah 1(a) menunjukkan uji kaji foto-fermentasi secara statik dan diaduk.
Bagi asai biohidrogen dalam fermentasi gelap, biojisim mikroalga digunakan sebagai sumber karbon tambahan kepada proses fermentasi. Penuaian biojisim mikroalga dimulakan dengan menggunakan kaedah pengemparan pada $8000 \mathrm{rpm}$ selama $10 \mathrm{~min}$. Seterusnya, biojisim dipisahkan secara manual dengan memisahkan biojisim yang terenap di bahagian bawah tiub emparan dan larutan cecair di bahagian atas. Emparan diulang sebanyak dua kali bagi memastikan biojisim yang dituai mempunyai kandungan cecair yang minima. Biojisim kemudiannya dituai menggunakan spatula dan dikeringkan dengan menggunakan kaedah pengeringan beku. Kandungan karbohidrat, protein dan lipid dalam biojisim mikroalga telah dianalisa masing-masing menggunakan kaedah yang diperkenalkan oleh Bligh dan Dyer (1959), Bradford (1976) dan Dubois et al. (1956). Bagi memastikan proses fermentasi gelap dijalankan secara anaerobik tanpa penghasilan oksigen disebabkan oleh proses fotosintesis, biojisim mikroalga disteril sebelum dicampur dengan enap cemar yang diperoleh daripada pencerna anaerobik efluen kilang kelapa sawit. Enap cemar ini diambil daripada pencerna anerobik di Kilang Kelapa Sawit Tennamaram, Bestari Jaya, Selangor, Malaysia sebagai sumber inokulum yang mengandungi bakteria anaerobik untuk penghasilan biohidrogen. Jadual 1 menunjukkan ciri enap cemar yang digunakan dalam uji kaji ini. Enap cemar yang mengandungi pelbagai spesies bakteria diberi rawatan haba pada suhu $80^{\circ} \mathrm{C}$ selama 30 min bagi memperkaya bakteria penghasil gas hidrogen (Mohd Yasin et al. 2011). Sebanyak $200 \mathrm{~mL}$ enap cemar yang telah diberi rawatan haba dicampur bersama $200 \mathrm{~mL}$ Reinforced Clostridium Media (RCM) di dalam botol Duran bersaiz $500 \mathrm{~mL}$. Kemudian, gas nitrogen disalurkan ke dalam campuran enap cemar dan RCM bagi menyingkirkan oksigen terlarut (Mohd Yasin et al. 2011). Campuran ini kemudian diaklimitasi pada suhu $50{ }^{\circ} \mathrm{C}$ dalam keadaan anaerobik selama 24 jam. Sebanyak $120 \mathrm{~mL}$ daripada campuran ini kemudiannya diinokulasi ke dalam $280 \mathrm{~mL}$ biojisim mikroalga yang telah diautoklaf. Uji kaji kawalan telah dijalankan dengan menggunakan air suling yang disteril bagi menggantikan biojisim mikroalga. Biojisim mikroalga ini berfungsi sebagai substrat kepada bakteria yang terdapat dalam enap cemar untuk menghasilkan gas hidrogen. Campuran enap cemar yang telah diaklimitasi dan biojisim mikroalga di dalam botol Duran disalurkan dengan gas nitrogen bagi menyingkirkan oksigen terlarut dan untuk mendapatkan keadaan anaerobik. Botol Duran kemudian diletakkan di dalam inkubator pada ketetapan suhu $50{ }^{\circ} \mathrm{C}$ pada keadaan statik dan dengan kawalan penggoncang pada kelajuan $100 \mathrm{rpm}$ sepanjang proses 
fermentasi. Rajah 1(b) menunjukkan uji kaji fermentasi gelap yang dijalankan. JADUAL 1. Ciri enap cemar yang digunakan dalam fermentasi gelap

\begin{tabular}{ccc}
\hline Parameter & Unit & \\
\hline $\mathrm{pH}$ & & 8.5 \\
Jumlah pepejal terampai (TSS) & $\mathrm{gL}^{-1}$ & 1.5 \\
SCOD & $\mathrm{mgL}^{-1}$ & $10853 \pm 119$ \\
Asid asetik & $\mathrm{mgL}^{-1}$ & $665 \pm 103$ \\
Asid butirik & $\mathrm{mgL}^{-1}$ & $42 \pm 28$ \\
Asid Propionik & $\mathrm{mgL}^{-1}$ & $103 \pm 30$ \\
Jumlah karbohidrat & $\mathrm{gL}^{-1}$ & $1.9-0.3$ \\
\hline
\end{tabular}

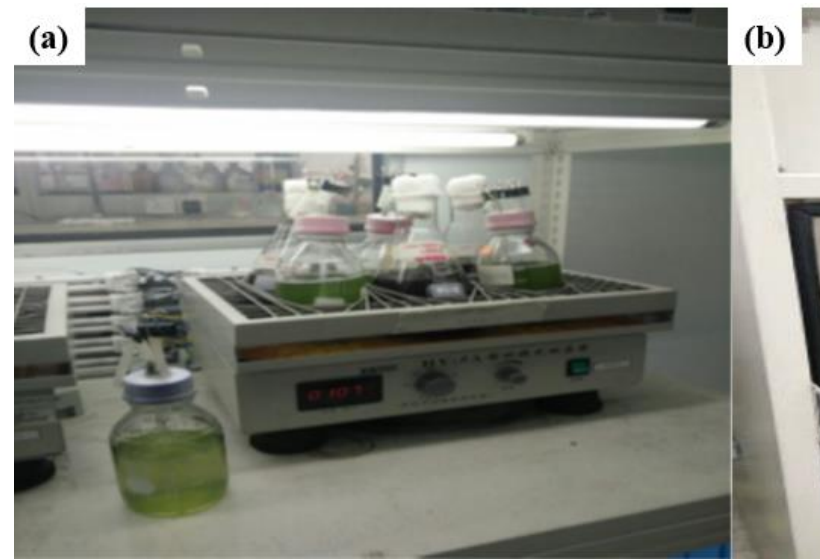

(b)
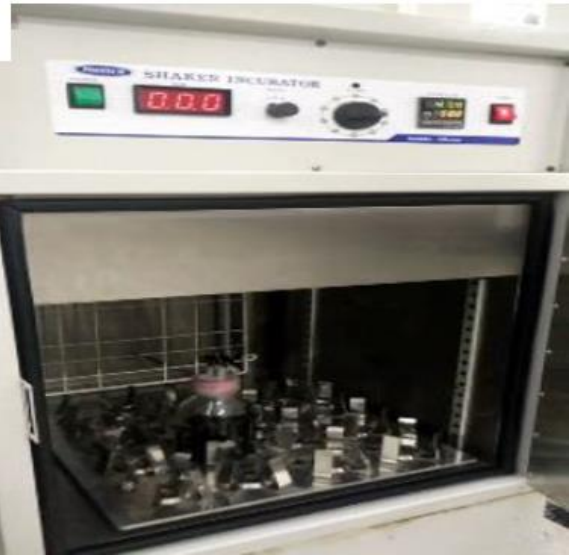

RAJAH 1. Asai biohidrogen dalam keadaan statik dengan bantuan penggoncang menggunakan kaedah (a) foto-fermentasi mikroalga Chlamydomonas sp. UKM6 dan (b) fermentasi gelap menggunakan biojisim mikroalga

\section{KAEDAH ANALISIS}

Analisis Keperluan Oksigen Kimia (COD) telah dijalankan dengan menggunakan kaedah yang disediakan oleh pengeluar (HACH, USA). $\mathrm{pH}$ dianalisa menggunakan meter Cyberscan pH 300 (Eutech Instrument). Untuk mengkaji kandungan asid asetik, asid butirik dan asid propionik di dalam sampel enap cemar, sampel telah diasidkan kepada $\mathrm{pH} 2$ dengan menggunakan $2 \mathrm{M}$ asid sulfurik. Kemudian, sampel disuntik kepada mesin Agilent 1100 Series HPLC yang dilengkapi dengan kolum Rozex ROA $(300 \times 7.8 \mathrm{~mm}$, saiz partikel $8 \mu \mathrm{m}, 00 \mathrm{H}-0138-\mathrm{K} 0$ ) menggunakan pengesan
UV-Vis pada sinaran $210 \mathrm{~nm}$. Sebanyak $0.005 \mathrm{~N}$ asid sulfurik digunakan sebagai fasa bergerak pada kelajuan $0.5 \mathrm{~mL} \mathrm{~min}^{-1}$ pada suhu $40{ }^{\circ} \mathrm{C}$.

\section{PEMBANGUNAN DAN SIMULASI SISTEM SUNTIKAN AUTOMATIK BAGI PEMANTAUAN GAS HIDROGEN}

Pembangunan sistem suntikan gas ini direka dengan menggunakan sensor hidrogen, injap dan pam. Sistem ini bertindak bagi mengawal aliran gas hidrogen yang terhasil oleh mikroalga dan disalurkan ke arah sel fuel membran penukar proton (PEM). Seperti sel fuel yang lain, PEM menggunakan tindak balas elektrokimia bagi 
menjana tenaga elektrik. Tindak balas berlaku apabila oksigen dan hidrogen bergabung untuk menghasilkan tenaga dan air sebagai hasil tindak balas. Tindak balas pengoksidaan berlaku di terminal katod dengan gas hidrogen menyumbang dua mol elektron dan menghasilkan ion hidrogen. Elektron dan ion hidrogen yang terhasil bertindak balas bersama gas oksigen di terminal katod dan perpindahan elektron daripada terminal anod ke katod menjana arus elektrik (Briguglio \& Antonucci 2016). Rajah 2 menunjukkan carta alir bagi sistem suntikan gas automatik yang dibangunkan.

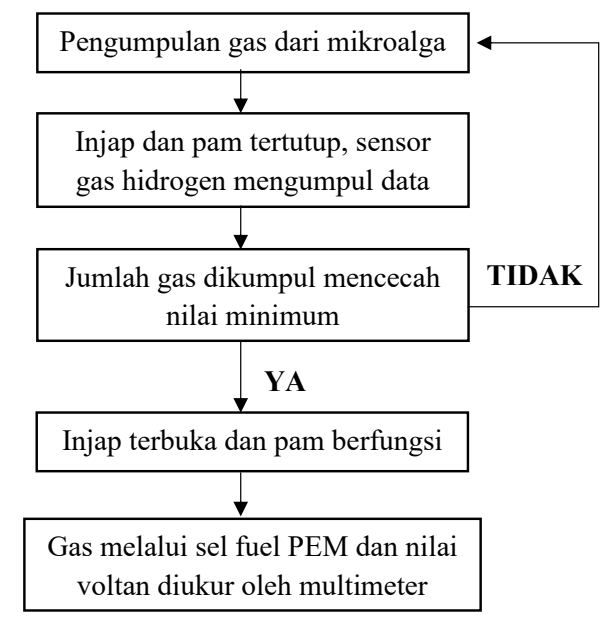

RAJAH 2. Carta alir bagi pembangunan sistem suntikan gas hidrogen secara automatik bagi penjanaan tenaga elektrik

Simulasi litar bagi pembangunan sistem suntikan automatik ini dijalankan dengan menggunakan perisian Proteus 8.1. Simulasi ini dilakukan bagi membuktikan kebolehupayaan sistem terutamanya pada interaksi antara sistem pengesanan dan sistem kawalan pergerakan yang mengawal fungsi injap dan pam. Rajah 3 menunjukkan litar yang digunakan dalam proses simulasi sistem suntikan gas hidrogen secara automatik yang mengandungi beberapa komponen dan bahagian, antaranya ialah Arduino Uno, pengesan gas hidrogen, suis geganti dan diod Zener, Litar Pemilih, serta paparan LCD dan LED.

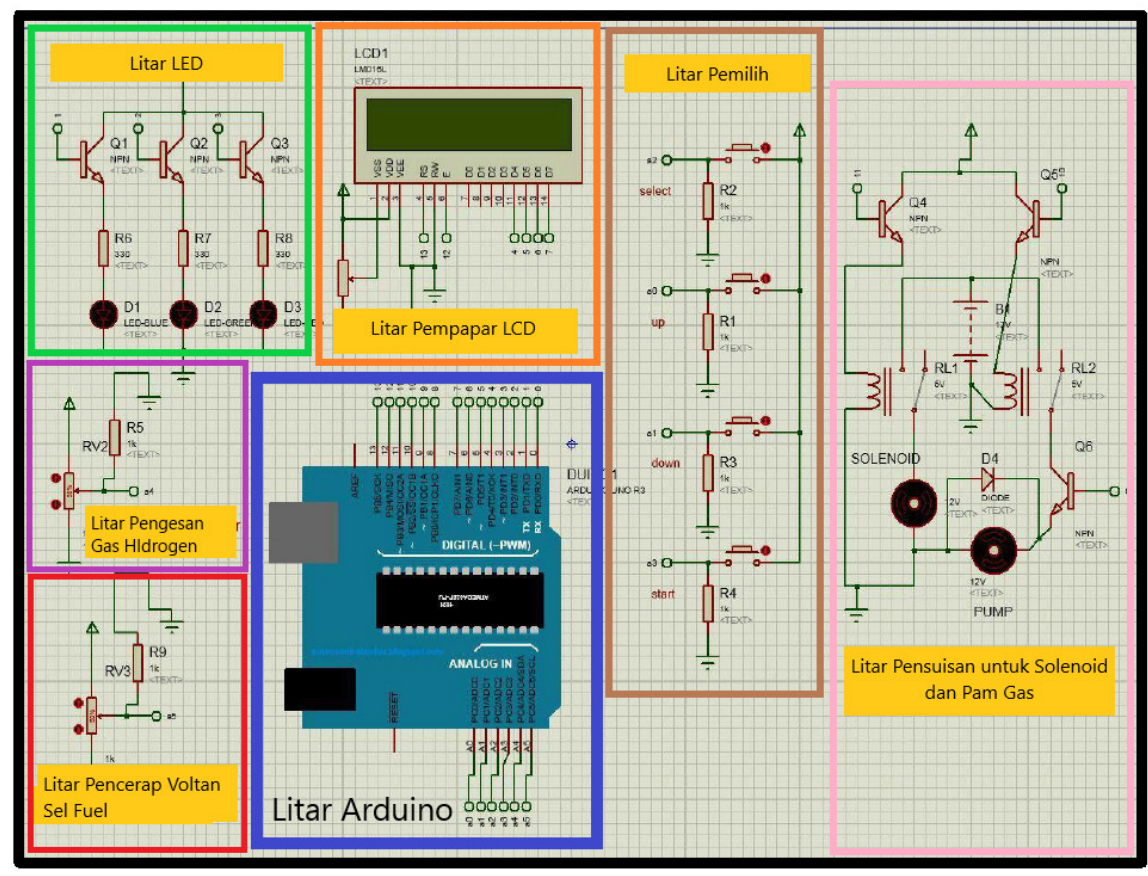

RAJAH 3. Reka bentuk litar sistem suntikan gas hidrogen secara automatik yang mengandungi pelbagai komponen dengan komponen litar Arduino sebagai komponen utama 
Penggunaan Arduino Uno mempunyai beberapa kelebihan iaitu ia litar yang lengkap dan sedia digunakan serta didatangkan bersama kawalan sebesar $5 \mathrm{~V}$, serta pengawal-mikro bagi memudahkan sambungan litar (Oussalem et al. 2019). Selain itu, sistem Arduino Uno merupakan platform elektronik sumber terbuka dan diserasikan dengan perisian yang boleh dikodkan secara manual. Pada litar lengkap, Arduino Uno bertindak sebagai pusat kawalan bagi membaca input yang diterima daripada sensor hidrogen dan memproses data melalui kod yang diprogramkan. Kod yang telah diprogramkan adalah bagi menetapkan isipadu gas hidrogen minimum bagi pembukaan injap serta menghidupkan pam bagi membolehkan aliran gas hidrogen.

Kod yang diprogramkan pada sistem Arduino Uno disusun di dalam Arduino melalui fail program jenis hex bagi menjalankan fungsi yang telah ditetapkan. Bagi sistem pengesanan gas hidrogen, sensor MQ-8 Hydrogen Sensor Module telah digunakan dan disambungkan pada penutup balang penuaian gas. Pengumpulan gas hidrogen mengambil masa selama 15 minit dan selepas setiap 10 saat, gas akan disedut melalui sensor gas hidrogen dan bacaan kepekatan gas hidrogen dipaparkan melalui antara muka perisian Arduino.

Penjanaan tenaga elektrik berlaku pada sel fuel PEM (daripada Horizon Education) yang dikelaskan sebagai sel fuel berlapis untuk menghasilkan tenaga di bawah 5W. Sel fuel PEM ini dipilih kerana mampu menghasilkan tenaga elektrik dengan jumlah gas hidrogen yang minimum. Sistem suntikan gas automatik yang mengandungi pelbagai komponen seperti Arduino Uno, multimeter, sel fuel PEM, sensor gas hidrogen dan botol Duran selepas asai biohidrogen disambungkan bagi melengkapkan uji kaji ini. Rajah 4 menunjukkan sambungan kesemua komponen yang terlibat.

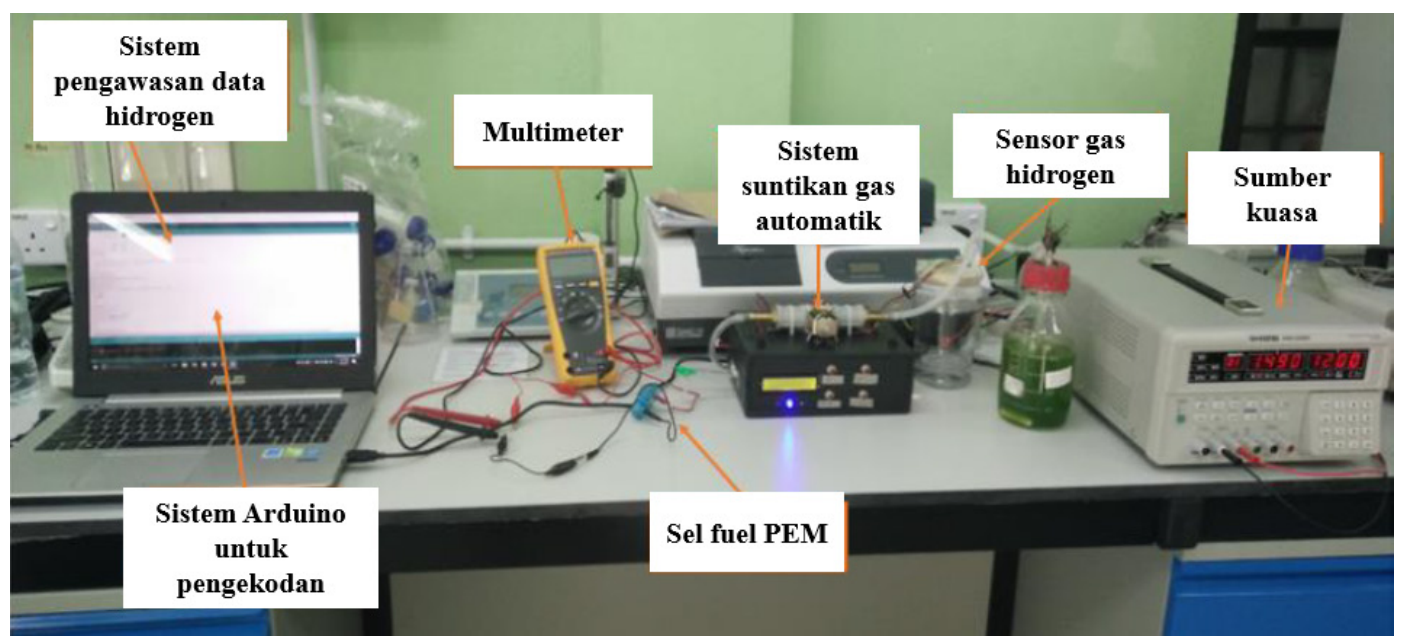

RAJAH 4. Sambungan komponen melibatkan Arduino Uno, multimeter, sel fuel PEM, sensor gas hidrogen dan sumber kuasa

\section{HASIL DAN PERBINCANGAN}

\section{PEMBANGUNAN DAN SIMULASI SISTEM SUNTIKAN GAS} HIDROGEN SECARA AUTOMATIK

Ujian simulasi telah dijalankan pada tiga titik utama bagi menguji keberjayaan simulasi yang dilakukan. Tiga titik utama itu ialah sensor gas hidrogen, injap solenoid dan pam gas. Ujian dilakukan secara automatik pada sensor gas hidrogen dan pam gas dan secara manual pada injap solenoid, pam gas dan sensor gas hidrogen.

Simulasi dijalankan dengan menetapkan aras kepekatan gas hidrogen yang dikesan pada sensor gas hidrogen pada kepekatan yang minimum dan maksimum. 
Tindak balas daripada simulasi ini ditunjukkan seperti keputusan yang diperoleh dalam Jadual 2. Berdasarkan keputusan yang diperoleh, sistem suntikan gas automatik ini berfungsi dengan baik pada kedua-dua pilihan simulasi. Sistem ini berjaya mengesan gas hidrogen pada kepekatan maksimum dan minimum untuk dijadikan sebagai input bagi Arduino. Pam gas juga didapati berjaya berfungsi dalam keadaan automatik dan manual.

Bagi memastikan bahawa sensor gas hidrogen MQ8 berfungsi dengan baik, uji kaji kalibrasi telah dijalankan.
Rajah 5 menunjukkan purata nilai gas hidrogen yang dibaca melalui sistem Arduino. Uji kaji ini dijalankan dengan menggunakan gas hidrogen dengan ketulenan $95 \%$ yang dipam dengan kelajuan yang berbeza $(5,10$, 20 dan $30 \mathrm{rpm}$ ). Setiap suntikan dipam sehingga tiada bacaan pada voltameter dan bacaan purata direkod di dalam sistem Arduino. Nilai garis regresi $\left(\mathrm{R}^{2}\right)$ yang terhasil adalah sebanyak 0.9224 yang menunjukkan bahawa sensor gas hidrogen berfungsi dengan baik kerana gas hidrogen yang

terhasil berkadar terus dengan kelajuan gas.

JADUAL 2. Keputusan simulasi yang dijalankan pada litar menggunakan perisian Proteus 8.1

\begin{tabular}{llcc}
\hline & Pilihan Butang & Proses yang dilakukan & Keputusan \\
\hline \multirow{5}{*}{ Automatik } & Sensor gas hidrogen & $\begin{array}{c}\text { Menetapkan parameter isipadu hidrogen maksimum } \\
\text { dan minimum bagi input Arduino }\end{array}$ & Berjaya \\
& Pam gas & $\begin{array}{c}\text { Menetapkan input maksimum dan minimum } \\
\text { menggunakan modulasi. Ini akan mengawal } \\
\text { kelajuan suntikan pam gas }\end{array}$ & Berjaya \\
\hline \multirow{2}{*}{ Manual } & Injap solenoid & Menguji pembukaan dan penutupan injap solenoid & Berjaya \\
& Pam gas & Menguji operasi pam gas & Berjaya \\
\hline
\end{tabular}

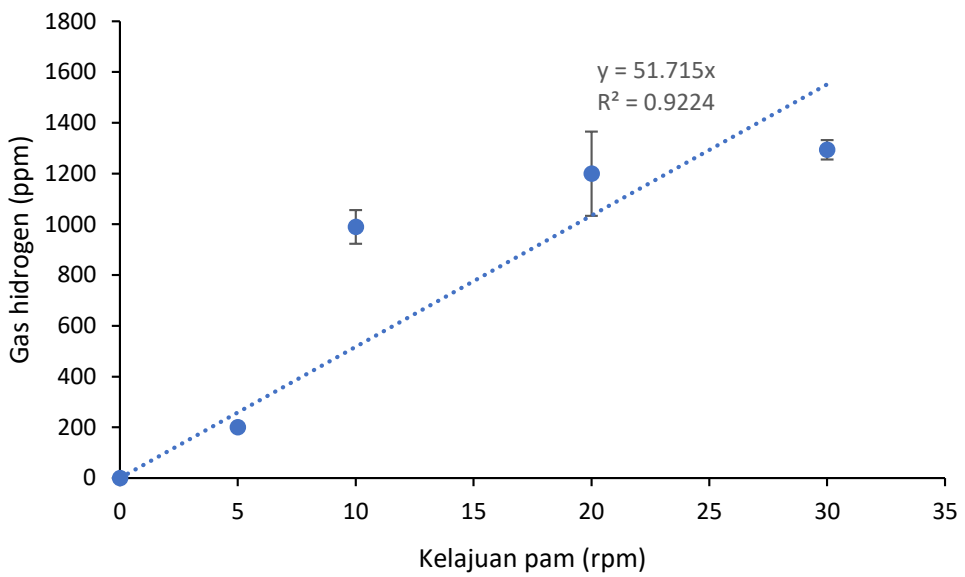

RAJAH 5. Uji kaji kalibrasi sensor gas hidrogen MQ8 


\section{PENGHASILAN GAS HIDROGEN DAN TENAGA YANG DIKULTUR SECARA STATIK DAN TERADUK DALAM FERMENTASI FOTOSINTESIS}

Chlamydomonas sp. UKM6 yang dikultur di dalam BBM dengan secara statik dan teraduk menunjukkan perbezaan jumlah sel yang ketara selepas 72 jam. Pertambahan kiraan sel dalam kultur teraduk telah dikenal pasti sebanyak 1.68 $\times 10^{5} \mathrm{sel} / \mathrm{mL}$ berbanding di dalam kultur statik $\left(1.05 \times 10^{5}\right.$ $\mathrm{sel} / \mathrm{mL}$ ). Kemudian, kedua-dua kultur ini telah disubkultur menggunakan media BBM yang tidak mengandungi unsur sulfur untuk proses foto-fermentasi secara anaerobik. Ketiadaan unsur sulfur mencetus keadaan anaerobiosis dengan mengubah laluan yang berlaku semasa proses fotosintesis untuk menghasilkan gas hidrogen berbanding oksigen (Anandraj et al. 2019).

Dengan menggunakan mikroalga yang dikultur secara statik dan teraduk sebagai benih mikroalga bagi proses foto-fermentasi anaerobik, dua kaedah yang sama seperti pengkulturan mikroalga secara statik dan teraduk diulang bagi penghasilan gas hidrogen. Gas yang terhasil bagi tempoh tiga hari dikumpul pada balang tuaian dan dikesan secara langsung oleh sistem suntikan automatik yang tersambung bersama Arduino dan juga sel fuel PEM. Keputusan bagi foto-fermentasi anaerobik yang dijalankan pada beberapa keadaan dibentangkan melalui Jadual 3 bagi memudahkan perbandingan dilakukan.

Foto-fermentasi anaerobik teraduk yang menggunakan mikroalga yang dikultur teraduk sebelumnya menghasilkan keputusan terbaik bagi kedua-dua keputusan iaitu purata kepekatan gas hidrogen $(26.99 \pm 1.24$ ppm) dan juga nilai voltan $(0.67 \mathrm{~V})$ yang terhasil. Selain itu, tidak terdapat banyak perbezaan dari segi nilai purata kepekatan gas hidrogen $(26.39 \pm 1.39 \mathrm{ppm})$ dan nilai voltan $(0.66 \mathrm{~V})$ yang terhasil daripada foto-fermentasi dalam keadaan teraduk menggunakan mikroalga yang sebelumnya dikultur secara statik. Uji kaji kawalan yang telah dijalankan menggunakan air suling steril bagi menggantikan mikroalga menunjukkan bahawa tiada gas hidrogen yang terhasil. Pengadukan semasa proses pengkulturan dan foto-fermentasi memastikan mikroalga tidak terkumpul hanya di sesuatu kawasan sahaja, ini mengehadkan pertumbuhan sel baharu akibat persaingan antara sel-sel baharu mikroalga. Ini juga membantu mikroalga untuk mencapai nutrien dan cahaya semasa fermentasi. Pengadukan membantu kelangsungan hidup mikroalga tanpa kesan bayangan yang merencatkan pertumbuhan mikroalga di dalam kultur (Uggetti et al. 2014). Kajian yang dijalankan oleh penyelidik terdahulu telah membuktikan pengadukan dalam proses pengkulturan mikroalga memberi pertumbuhan yang positif terutamanya terhadap kadar pertumbuhan mikroalga (Hariz et al. 2018; Minhat et al. 2016). Namun begitu, pengadukan tidak memberi kesan terhadap hasil gas hidrogen dan nilai voltan berbanding kaedah statik (Jadual 2). Dapat disimpulkan bahawa kedua-dua kaedah menghasilkan gas hidrogen dan nilai voltan yang tidak ketara. Namun begitu, kecekapan sistem Arduino dengan sensor MQ8 jelas menunjukkan pengesanan gas hidrogen dapat dilakukan secara ringkas dan segerak dengan kos yang lebih rendah berbanding penggunaan Rasberry pi dan kromatografi gas.

Ketepatan dalam kuantifikasi secara segerak menggunakan sistem ini bergantung kepada beberapa faktor utama iaitu ketepatan sensor gas yang digunakan, kadar aliran gas yang stabil serta sesuai bagi penghasilan tenaga (voltan) dalam menyampaikan gas dari balang kultur sehingga ke sel fuel PEM. Wahdame et al. (2006) telah mengkaji kesan aliran dan tekanan gas terhadap tenaga yang terhasil menggunakan sel fuel yang lebih besar iaitu 500W. Kajian oleh Guvelioglu dan Stenger (2007) juga menyatakan bahawa tenaga yang terhasil bergantung kepada beberapa faktor dan kadar aliran merupakan salah satu yang memberi impak kepada jumlah tenaga terhasil. Sehubungan dengan itu dapat disimpulkan bahawa kadar aliran gas merupakan salah satu penyebab mengapa tenaga pada mikroalgal teraduk dan mikroalgal dikultur statik yang dihasilkan hampir menyerupai walaupun terdapat perbezaan jelas pada nilai kepekatan (ppm) purata gas hidrogen yang terhasil. Walaupun hanya terdapat sedikit perbezaan yang terlihat, kajian ini memberikan impak serta kebaharuan kajian berkaitan mikroalga tempatan menjana gas hidrogen yang dijana terus menggunakan teknologi

Internet of Things (IoT).

JADUAL 3. Keputusan foto-fermentasi bagi pelbagai kaedah uji kaji

\begin{tabular}{ccccc}
\hline & \multicolumn{2}{c}{ Mikroalgal dikultur teraduk } & \multicolumn{2}{c}{ Mikroalgal dikultur statik } \\
\hline & $\begin{array}{c}\text { Foto-fermentasi } \\
\text { anaerobik teraduk }\end{array}$ & $\begin{array}{c}\text { Foto-fermentasi } \\
\text { anaerobik statik }\end{array}$ & $\begin{array}{c}\text { Foto-fermentasi } \\
\text { anaerobik teraduk }\end{array}$ & $\begin{array}{c}\text { Foto fermentasi } \\
\text { anaerobik statik }\end{array}$ \\
\hline $\begin{array}{c}\text { Purata gas hidrogen } \\
(\mathrm{ppm})\end{array}$ & $26.99 \pm 1.24$ & $23.33 \pm 1.18$ & $26.39 \pm 1.39$ & $22.93 \pm 1.95$ \\
Nilai voltan $(\mathrm{mV})$ & $0.67 \pm 0.12$ & $0.46 \pm 0.17$ & $0.66 \pm 0.11$ & $0.44 \pm 0.17$ \\
\hline
\end{tabular}

*Tiada gas hidrogen yang terhasil dalam uji kaji kawalan 
PENGHASILAN GAS HIDROGEN DAN TENAGA MELALUI FERMENTASI GELAP SETELAH DIKULTUR SECARA STATIK DAN TERADUK

Biojisim mikroalga, Chlamydomonas sp. UKM6 difermentasi dalam keadaan gelap menggunakan dua kaedah pengkulturan iaitu statik dan secara teraduk. Biojisim mikroalga digunakan sebagai substrat dalam kajian ini bagi membekalkan bahan organik dalam pencuraian anaerobik bagi menghasilkan biohidrogen. Komposisi biojisim Chlamydomonas sp. UKM6 yang digunakan terdiri daripada karbohidrat, protein dan lipid masing-masing pada 14 dan $13 \%$ dan selebihnya merupakan komponen lain. Komponen lipid dan karbohidrat di dalam biojisim mikroalga telah digunakan secara meluas oleh penyelidik lain untuk menghasilkan biohidrogen secara fermentasi anaerobik (Liu et al. 2012; Yang et al. 2011).

Rajah 6 menunjukkan purata bagi kepekatan gas hidrogen dan nilai voltan bagi fermentasi gelap yang menggunakan biojisim mikroalga sebagai substrat sepanjang tempoh suntikan automatik ke dalam sistem sel fuel. Gas hidrogen yang telah terkumpul selama 3 hari di ruang udara botol Duran telah disalurkan ke dalam sistem Arduino selama 15 min (900 s). Biogas di ruang udara telah disedut menggunakan pam dan biohidrogen yang terhasil terus dinilai menggunakan sistem pengawasan data Arduino seperti dalam Rajah 4. Gas hidrogen didapati banyak terhasil pada saat ke 120 ke 400 sahaja kerana pada saat ini, biogas yang terkumpul dapat dipam sepenuhnya ke dalam sel fuel PEM. Selepas saat ke 400, hanya baki biogas yang tertinggal sahaja dipam ke dalam sistem. Justeru, gas hidrogen dan nilai voltan menurun selepas saat ke 400 (Rajah 6). Penurunan nilai voltan yang terhasil disumbangkan oleh beberapa faktor sepert tekanan gas hidrogen yang telah menurun setelah gas dipam ke sel fuel PEM. Kajian mendapati, tekanan gas juga memberikan kesan dalam menghasilkan nilai voltan. Kajian awal yang dilakukan oleh Barbir et al. (2005) juga mendapati tekanan gas serta kejatuhan tekanan setelah gas dipam memberikan kesan terhadap prestasi sel fuel dalam menjana nilai voltan.

Berdasarkan keputusan yang diperoleh, dapat dilihat bahawa penghasilan gas hidrogen lebih tinggi dalam keadaan teraduk $(30.89 \pm 1.68 \mathrm{ppm})$ berbanding statik $(29.59 \pm 3.79 \mathrm{ppm})$ tetapi tiada perbezaan yang ketara antara dua kaedah ini. Selain itu, nilai hidrogen maksimum berjaya mencecah sebanyak 44 ppm untuk uji kaji menggunakan pengaduk selepas 160 saat disuntik secara automatik ke dalam sistem sel fuel ini. Nilai hidrogen maksimum bagi uji kaji dalam keadaan statik adalah sebanyak 36 ppm selepas 120 s suntikan automatik.
Keputusan ini menunjukkan bahawa proses pengadukan menggalakkan lagi pembebasan gas biohidrogen ke udara dan tidak membenarkan gas tersebut terkumpul di dalam media.

Setelah nilai kepekatan gas hidrogen bagi proses fermentasi gelap diperoleh, nilai voltan yang dijana oleh PEM sel fuel juga turut dibandingkan bagi fermentasi gelap seperti dalam Rajah 5(b). Berdasarkan keputusan yang diperoleh, nilai purata voltan yang terhasil adalah lebih tinggi pada fermentasi gelap yang menggunakan mikroalga yang dikultur secara teraduk iaitu pada nilai purata sebanyak $0.92 \pm 0.10 \mathrm{mV}$ berbanding $0.83 \pm 0.21$ $\mathrm{mV}$ dalam kultur statik. Rajah 6(b) menunjukkan nilai voltan yang jauh lebih tinggi dalam fermentasi gelap kultur teraduk berbanding kultur statik. Keputusan yang diperoleh menunjukkan bahawa sistem sel fuel PEM dapat menghasilkan jumlah tenaga sebanyak $0.03 \mathrm{mV}$ bagi setiap $1 \mathrm{ppm}$ gas hidrogen yang terhasil.

Uji kaji kawalan menunjukkan jumlah gas hidrogen (Rajah 6(a)) dan voltan (Rajah 6(b)) yang rendah berbanding dengan uji kaji yang menggunakan biojisim mikroalga. Ini membuktikan bahawa biohidrogen yang terhasil adalah daripada biojisim mikroalga itu sendiri. Namun begitu, masih terdapat biohidrogen dan juga voltan yang terhasil dalam uji kaji kawalan disebabkan oleh enap cemar yang digunakan mempunyai komponen karbohidrat (1.9-0.3 $\left.\mathrm{gL}^{-1}\right)$, asid asetik $\left(665 \pm 103 \mathrm{mgL}^{-1}\right)$ dan asid butirik $\left(42 \pm 28 \mathrm{mgL}^{-1}\right)$ seperti yang dinyatakan dalam Jadual 1. Ketiga-tiga komponen ini menyumbang kepada penghasilan biohidrogen dalam fermentasi anaerobik (Mohd Yasin et al. 2011).

Perbandingan yang diperoleh daripada kultur fermentasi fotosintesis dan gelap menunjukkan bahawa fermentasi gelap dapat menjana lebih gas hidrogen dan voltan yang terhasil masing-masing mencapai nilai maksimum sebanyak $44 \mathrm{ppm}$ dan $1.7 \mathrm{mV}$, berbanding kultur foto-fermentasi yang hanya menjana gas hidrogen dan voltan masing-masing sebanyak $26 \mathrm{ppm}$ dan 0.67 $\mathrm{mV}$. Justeru, biojisim mikroalga didapati lebih sesuai digunakan untuk penghasilan biohidrogen dalam keadaan anaerobik menggunakan bakteria sedia ada dalam enap cemar efluen kelapa sawit daripada sistem pencerna anaerobik. Selain daripada itu, proses pengadukan adalah sangat penting untuk memastikan gas hidrogen yang terhasil tidak terlarut di dalam media untuk memastikan tekanan separa yang rendah. Kecekapan penghasilan biohidrogen di dalam reaktor sangat bergantung kepada tekanan separa yang rendah bagi memastikan gas hidrogen yang terhasil tidak terkumpul di ruang tutupan di dalam reaktor. Tekanan separa yang tinggi di dalam ruang tutupan reaktor mengganggu kecekapan penghasilan hidrogen (Balachandar et al. 2013). Sistem sel fuel yang direka dalam kajian ini juga dapat membantu pencerapan gas hidrogen secara berkesan daripada kultur biologi. 
(a)

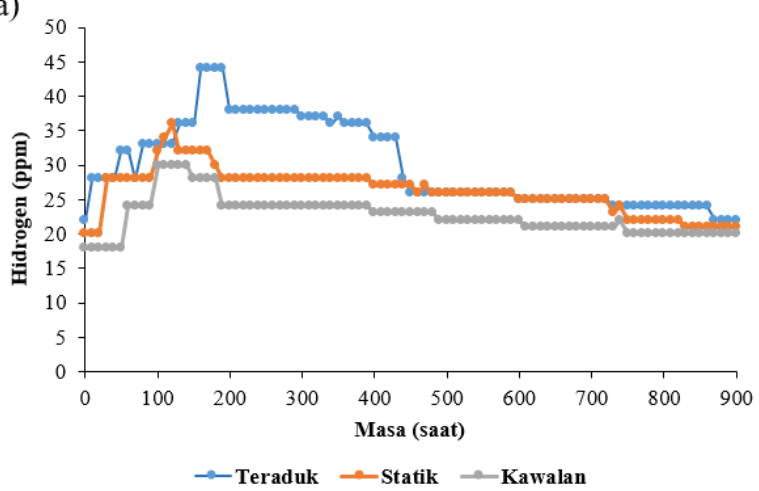

(b)

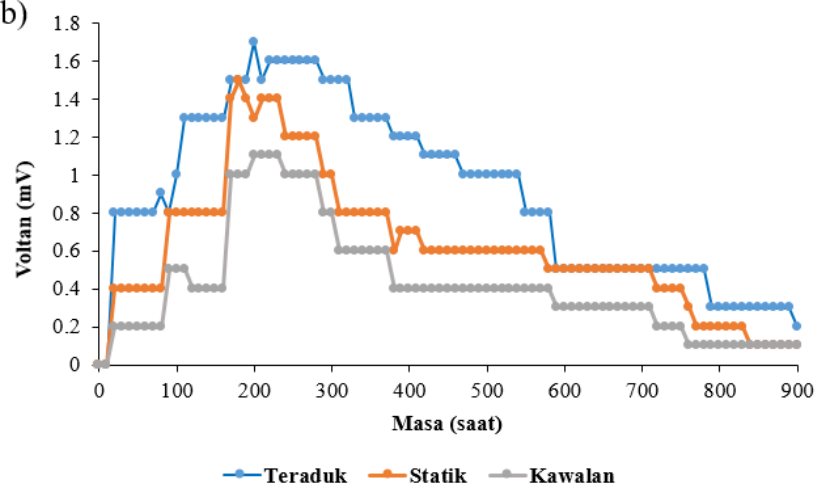

RAJAH 6. (a) Purata gas hidrogen dan (b) nilai voltan yang terhasil selepas disuntik secara automatik ke dalam sistem sel fuel bagi fermentasi gelap yang dikultur secara statik dan teraduk menggunakan biojisim mikroalga. Uji kaji kawalan menggunakan air suling steril bagi menggantikan biojisim mikroalga

\section{KESIMPULAN}

Pembangunan sistem suntikan automatik gas hidrogen yang dibangunkan dengan menggunakan Arduino Uno telah terbukti berkesan dan ini dapat dibuktikan berdasar simulasi yang dilakukan menggunakan Perisian Proteus 8.1. Keputusan simulasi menunjukkan kesemua pilihan yang ditetapkan secara manual dan automatik telah berjaya dilakukan pada ketiga-tiga sensor gas hidrogen, pam gas dan injap solenoid. Pengkulturan mikroalga dalam kedua-dua fermentasi fotosintesis dan gelap menunjukkan bahawa pengadukan telah memberi impak positif terhadap nilai hidrogen dan voltan yang terhasil. Selain itu, proses fermentasi gelap menggunakan biojisim mikroalga juga telah menunjukkan kesesuaian dalam penjanaan lebih gas hidrogen dan tenaga berdasarkan nilai voltan yang terhasil. Oleh itu, dapat disimpulkan bahawa mikroalga berpotensi dalam menghasilkan tenaga melalui gas hidrogen. Fermentasi biologi ini dapat terus disukat dan disimulasi menggunakan sistem sel fuel yang direka dalam kajian ini. Sistem ini dapat diperbaiki lagi pada masa akan datang untuk penjanaan tenaga yang lebih cekap menggunakan sumber biologi.

\section{PENGHARGAAN}

Penghargaan diberikan kepada Geran Universiti Penyelidikan (GUP-2018-118) kerana menyumbang dana sepanjang tempoh penyelidikan ini dijalankan.

\section{RUJUKAN}

Anandraj, A., White, S. \& Mutanda, T. 2019. Photosystem I fluorescence as a physiological indicator of hydrogen production in Chlamydomonas reinhardtii. Bioresource Technology 273: 313-319.

Anwar, M., Lou, S., Chen, L., Li, H. \& Hu, Z. 2019. Recent advancement and strategy on bio-hydrogen production from photosynthetic microalgae. Bioresource Technology 292: 121972.

Balachandar, G., Khanna, N. \& Das, D. 2013. Biohydrogen production from organic wastes by dark fermentation. In Biohydrogen, edited by Pandey, A., Chang, J.S., Hallenbeck, P. \& Larroche, C. Burlington, USA: Elsevier, Inc. pp. 103144.

Barbir, F., Gorgun, H. \& Wang, X. 2005. Relationship between pressure drop and cell resistance as a diagnostic tool for PEM feul cells. Journal of Power Sources 141(1): 96-101.

Becker, W. 2007. Microalgae in human and animal nutrition. Handbook of Microalgae Cultivation. pp. 312-351.

Bisták, P. 2019. Arduino support for personalized learning of controil theory basics. IFAC-PapersOnLine 52(27): 217221.

Bligh, E.G. \& Dyer, W.J. 1959. A rapid method of total lipid extraction and purification. Canadian Journal of Biochemistry and Physiology 37(8): 911-917.

Bolatkhan, K., Kossalbayev, B.D., Zayadan, B.K., Tomo, T., Veziroglu, T.N. \& Allakhverdiev, S.I. 2019. Hydrogen production from phototrophic microorganisms: Reality and perspectives. International Journal of Hydrogen Energy 44(12): 5799-5811. 
Bradford, M.M. 1976. Rapid and sensitive method for the quantification microgram quantities of protein utilizing the principle of protein-dye binding. Analytical Biochemistry 72(1-2): 248-254.

Briguglio, N. \& Antonucci, V. 2016. Hydrogen production: Overview of PEM electrolysis for hydrogen production. In PEM Electrolysis for Hydrogen Production: Principles and Applications, edited by Bessarabov, D., Wang, H., Li, H. $\&$ Zhao, N. Boca Raton: CRC Press. pp. 1-3.

Dubois, M., Gilles, K.A., Hamilton, J.K., Rebers, P.A. \& Smith, F. 1956. Colorimetric method for determination of sugars and related substances. Analytical Chemistry 28(3): 350-356.

Guvelioglu, G.H. \& Stenger, H.G. 2007. Flow rate and hunidification effects on a PEM fuel cell performance and operation. Journal of Power Sources 163(2): 882-891.

Hariz, H.B., Takriff, M.S., Ba-Abbad, M.M., Mohd Yasin, N.H. \& Takriff, M.S. 2018. $\mathrm{CO}_{2}$ fixation capability of Chlorella sp. and its use in treating agricultural wastewater. Journal of Applied Phycology 30(6): 3017-3027.

Hazman, N.A.S., Mohd Yasin, N.H., Takriff, M.S., Hasan, H.A., Kamarudin, K.F. \& Hakimi, N.I.N.M. 2018. Integrated palm oil mill effluent treatment and $\mathrm{CO}_{2}$ sequestration by microalgae. Sains Malaysiana 47(7): 1455-1464.

Jones, C.S. \& Mayfield, S.P. 2012. Algae biofuels: Versatility for the future of bioenergy. Current Opinion in Biotechnology 23(3): 346-351.

Kumar, M.D., Kaliappan, S., Gopikumar, S., Zhen, G. \& Banu, JR. 2019. Synergetic pretreatment of algal biomass through $\mathrm{H}_{2} \mathrm{O}_{2}$ induced microwave in acidic condition for biohydrogen production. Fuel 253: 833-839.

Liu, C.H., Chang, C.Y., Cheng, C.L., Lee, D.J. \& Chang, J.S. 2012. Fermentative hydrogen production by Clostridium butyricum CGS5 using carbohydrate-rich microalgal biomass as feedstock. International Journal of Hydrogen Energy 37(20): 15458-15464.

Minhat, Z., Rahaman, M.S.A., Takriff, M.S. \& Kofli, N.T. 2016. Differentiation of biomass composition between isolated and commercial strains of microalgae. Journal of Engineering Science and Technology 11(5): 737-744.

Miskon, A., Thanakodi, S., Nazar, N.S.M., Chong, M.W.K., Takriff, M.S., Norzali, A.A. \& Tawil, S.N.M. 2016. Feasibility studies of vortex flow impact on the proliferation of algae in hydrogen production for fuel cell applications. IOP Conference Series: Material Science and Engineering 160: $1-8$

Mohd Yasin, N.H., Ikegami, A., Wood, T.K., Yu, C.P., Haruyama, T., Takriff, M.S. \& Maeda, T. 2017. Oceans as bioenergy pools for methane production using activated methanogens in waste sewage sludge. Applied Energy 202(15): 399-407.

Mohd Yasin, N.H., Abd Rahman, N.A., Man, H.C, Mohd Yusoff, M.Z. \& Hassan, M.A. 2011. Microbial characterization of hydrogen-producing bacteria in fermented food waste at different $\mathrm{pH}$ values. International Journal of Hydrogen Energy 36(16): 9571-9580.
Oltean, S.E. 2019. Mobile robot platform with Arduino Uno and Raspberrry Pi for autonomous navigation. In The 12th International Conference Interdisciplinarity in Engineering. Procedia Manufacturing. 32: 572-577.

Oussalem, O., Kourchi, M., Rachday, A., Ajaamoum, M., Idadoub, H. \& Jenkal, S. 2019. A low cost controller of PV system based on Arduino board and INC algorithm. Materials Today: Proceedings 24: 104-109.

Templeton, D.W., Quinn, M., Van Wychen, S., Hyman, D. \& Laurens, L.M.L. 2012. Separation and quantification of microalgal carbohydrates. Journal of Chromatography A 1270: 225-234.

Uggetti, E., Sialve, B., Latrille, E. \& Steyer, J.P. 2014. Anaerobic digestate as substrate for microalgae culture: The role of ammonium concentration on the microalgae productivity. Bioresource Technology 152: 437-443.

Wahdame, B., Candusso, D. \& Kauffmann, J.M. 2006. Study of gas pressure and flow rate influences on a $500 \mathrm{~W}$ PEM fuel cell,thanks to the experimental design methodology. Journal of Power Sources 156(1): 92-99.

Yang, Z., Guo, R., Xu, X., Fan, X. \& Luo, S. 2011. Hydrogen and methane production from lipid-extracted microalgal biomass residues. International Journal of Hydrogen Energy 36(5): 3465-3470.

Yang, S., Liu, Y., Wu, N., Zhang, Y., Svoronos, S. \& Pullammanappallil, P. 2019. Low-cost, Arduino-based, portable device for measurement of methane composition in biogas. Renewable Energy 138: 224-229.

Kamrul Fakir Kamarudin \& Mohd Sobri Takrif

Jabatan Kejuruteraan Kimia dan Proses

Fakulti Kejuruteraan dan Alam Bina

Universiti Kebangsaan Malaysia

43600 UKM Bangi, Selangor Darul Ehsan

Malaysia

Kamrul Fakir Kamarudin

Fakulti Sains dan Teknologi Industri

Universiti Malaysia Pahang

Lebuhraya Tun Razak

26300 Kuantan, Pahang Darul Makmur

Malaysia

Nur Farah Mohd Shukuri \& Azizi Miskon

Jabatan Kejuruteraan Elektrikal dan Elektronik

Fakulti Kejuruteraan

Universiti Pertahanan Nasional Malaysia

Kem Sg. Besi, 57000 Kuala Lumpur, Wilayah Persekutuan Malaysia

Nur Farah Mohd Shukuri

Institut Penerbangan 1

Kolej Tentera Udara

06200 Kepala Batas, Alor Setar, Kedah Darul Aman

Malaysia 
Nazlina Haiza Mohd Yasin*

Jabatan Sains Biologi dan Bioteknologi

Fakulti Sains dan Teknologi

Universiti Kebangsaan Malaysia

43600 UKM Bangi, Selangor Darul Ehsan

Malaysia

Suresh Thanakodi

Jabatan Sains dan Teknologi Maritim

Fakulti Sains dan Teknologi Pertahanan

Universiti Pertahanan Nasional Malaysia

Kem Sg. Besi, 57000 Kuala Lumpur, Wilayah Persekutuan Malaysia
Suresh Thanakodi

Pusat Kecemerlangan Penyelidikan Maritim (MAREC)

Universiti Pertahanan Nasional Malaysia

Kem Sg. Besi, 57000 Kuala Lumpur, Wilayah Persekutuan

Malaysia

*Pengarang untuk surat-menyurat; email: nazlinayasin@ukm.

edu.my

Diserahkan: 3 Oktober 2019

Diterima: 3 Oktober 2020 